THE 13th INTERNATIONAL CONFERENCE OF

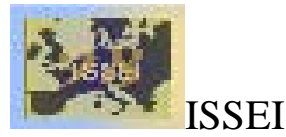

International Society for the Study of European Ideas

in cooperation with the University of Cyprus

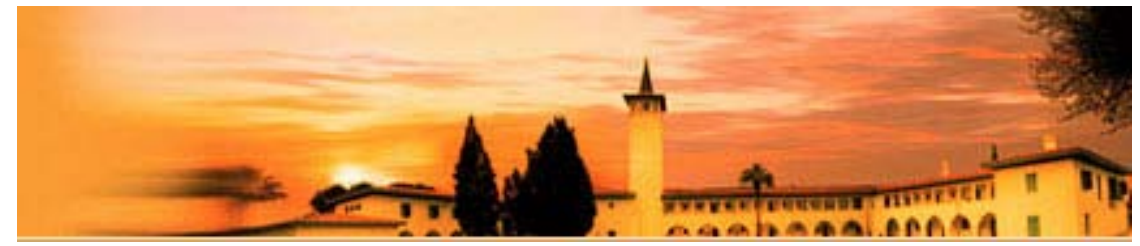

\title{
Memory of the body, Temptation of Space.
}

Luís António Umbelino

Auxiliar Professor

Facullty of Humanities - Universidade de Coimbra - Portugal

Largo da Porta Férrea

3004-530 Coimbra

Portugal

luis.um@megamail.pt

lumbelino@fl.uc.pt

\section{Introduction: the shared destiny of time and space.}

Let me start with a simple statement: there's something like a spatial environment inherent in the traces of memory ${ }^{1}$. As we remember the past to try to tell it to someone close to us, memories of joy will be attached to the rooms and objects of our childhood house, ideas and feelings of wonder will be found linked to the spaces of that museum once visited, friendship will be linked to, say, a table in a café, love to a hotel near the sea, peace to a landscape that once captured our heart, disappointment to a closed door of a monument we so wanted to visit, fatigue to that bench we sat on when we were lost, far from our hotel in that city that we visited for the first time. In each

\footnotetext{
${ }^{1}$ Paul Ricœur, La mémoire, l'histoire, l’oublie (Seuil, Poche Essais, 2000), 184.
} 
case, these places are never something we add to an already complete memory of something; quite on the contrary, when we remember, it is as if memory were made in those places, as if it were built-up by being anchored to these spaces, and as if, so to speak, time and space were always bound together. Memory thus seems to show the intertwining of time and space. Moreover, as we revisit some of those places, some memories became clearer and others only then are discovered. They are made in those places and memory seems to be kept by these places, as if waiting for our return to present us with our own memories. All this implies that memory is never placeless.

This seems to be true not only from an individual point of view, but also from a collective perspective. Because our memories are something that we share, they are always, at the same time, something intimate and connected with the memories of others. In fact, it is often hard to know precisely where our memories end and the memories of others begin. In this sense, to share memories with those that are closed to us is just a few steps away from "collective memory" with its commemorations that are linked to - in the well known expression from P. Nora - "places of memory." In these places full of time, the relation between space and memory is, as Halbwachs shows, a double one: on the one hand, space is the material reference where the images of what is no longer present are anchored; on the other, space becomes an archive for actualized (imagined, transformed) memories, hence giving the groups the chance to access a time of belonging.

Memory - both personal and collective - has its geography. It has its own spatiality. In this sense, we are going to argue that memory, usually analysed primary from the point of view of time, demands to be approached from the point of view of space. 


\section{The memory of the body.}

To approach the space/time relation "on the side of space”, we can begin by turning to E. Casey's ${ }^{2}$ project of a phenomenology of place. Here, the first level of analysis brings us to consider, as an original reference, the spatiality of the body; that is to say, we start from the original strangeness of being a body always requested by space, of being a body whose experiences all convey - as Merleau-Ponty puts it - an “already acquired spatiality."3

This acquired spatiality is revealed, before any explicit thematisation, in the way the lived dimension of the body ${ }^{4}$ merges with the lived logic of space. ${ }^{5}$ This fact is first found in that enigmatic synchronized familiarity composed by the lived body's perceptive and motor dispositions and by the lived space that constantly encourages certain gestures, postures, movements and choices in the lived body.

For the body, to be in place is to occupy the centre of an oriented space. It is to be in relation to that corporal centre that is impossible for usto leave and that we constantly carry with us. It is in terms of this centre that the basic dissymmetrical relations and structures of space are sketched. As E. Casey explains, we must first of all consider here "the binary character of these structures" as they reflect "upright posture, the bilaterality of our body (its dissymmetricality of organs and functions) and, more generally, the function of the lived body as a basis of orientation." ${ }^{6}$ This is a key feature

\footnotetext{
2 Edward Casey, Getting Back into Place, (2nd ed., Indiana University Press, Bloomington and Indianapolis, 2009). We are following here Ricœur, La mémoire..., 185.

${ }^{3}$ Maurice Merleau-Ponty, Phénoménologie de la perception (Gallimard, Paris, 1945), 293.

${ }^{4}$ Merleau-Ponty, Phénoménologie, 90.

${ }^{5}$ Merleau-Ponty, Phénoménologie, 61.

${ }^{6}$ Casey, Getting Back..., 48.
} 
since "in keeping with its own ambidextrous proclivities, this body tends toward bifurcation (not to be confused with geometric bisection), arranging its choices, directions, and movements, as right-left, near-far, up-down, above-below,” here-there, etc. ${ }^{7}$ These structures and postures, along with the axes of interest they inscribe in space, disclose a space that is never, for the body, a neutral, and homogenous (Cartesian, Euclidian, Newtonian $^{8}$ ) reality. For the body, space has different intensities: it can be lived as "light” or "heavy," "harsh" or "friendly," “open” or "blocked." Furthermore space is susceptible of gaining different values. ${ }^{9}$ We extend our "right hand" to those we respect, we despise those who "come crawling," we admire those who "look you in the eye," and we despise those who stab us in the "back." Even in the darkest of moments, we want to get back "on our feet," we will never "give way" the to difficulties that "face" us, and we will "rise" to the occasion.

To be in space as a body means to have a place; but to have a place never equals to be located in a fixed point of a neutral extension. By means of the dynamism of the body, space is signified by praxic incorporation (the "praktognosie" ${ }^{10}$ Merleau-Ponty talks about), that is to say, by the "architectonics of a corporality that is (...) the architecture of the world." ${ }^{11}$ The way of being of the body is the measure of a "spatiality of situation" that is phenomenologically different from the partes extra partes of a "spatiality of localization." The axes of such a measure are the corporal schema understood as an intersensorial and intercorporal organizations of

\footnotetext{
${ }^{7}$ Casey, Getting Back..., 48.

${ }^{8}$ Ricoeur, La mémoire..., p. 185.

9 O. F., Bollnow, Hombre et espacio (spanish translation, Biblioteca Universitaria Labor, Barcelona, 1969), 49.

${ }^{10}$ Merleau-Ponty, Phénoménologie, 164

${ }^{11}$ Emmanuel de Saint Aubert, «Espace et schéma corporel dans la philosophie de la chair de MerleauPonty », in Alain Berthoz, Bernard Andrieu (org.) Le corps en acte (Presse Universitaire de Nancy, 2010), 126.
} 
implications. ${ }^{12}$ That is to say, the body we are is deeply involved in space to the point that its cohesion varies to the rhythm of the relation of our intertwining with it. Thus, if the body is a measure of space, ${ }^{13}$ it is such insofar as the body is already intertwined with (demanded, situated by) the space a person belongs to. In other words, the body is a measure of space only to the extent that a person is part of space, i.e., involved in it. This means that he finds in it the other side of his active being-in-the-world. Consequently, the body is a condition of the phenomenality of space because the person is always already within what he is conditioning; that is to say, he conditions only because he is previously conditioned by what he conditions; he is a measure only because he is measured by what he measures. As Merleau-Ponty puts it, the body is a topological "open unity." It is a "knot of lived significations"14 that we must recognize as a correlative of an "open unity." What we confront here is a "unity of style more than of significance, a unity that characterizes the world." ${ }^{15}$

Such a correlation, such a mutual involvement of body and space, sustains an original flow of time and memory. Where else, but in the way the body is made a "constant" and "durable" act of dis-position, co-respondance by the constant and archaic - pre-personal, anonymous - demands of space, could we find the first sketches of time and memory? To show this, we have to analyze the "memory of the body" that

\footnotetext{
${ }^{12}$ Saint Aubert, « Espace et schéma corporel ... », 124; 128-129. See Merleau-Ponty, Phénoménologie..., 114.

${ }^{13}$ Merleau-Ponty, Phénoménologie..., 161 : «La conscience est l’être à la chose par l’intermédiaire du corps. Un mouvement est appris lorsque le corps l'a compris, c'est-à-dire lorsqu'il l'a incorporé à son 'monde', et mouvoir son corps c'est viser à travers lui les choses, c'est laisser répondre à leur sollicitation qui s’exerce sur lui sans aucune représentation.»

${ }^{14}$ Merleau-Ponty, Phénoménologie..., 177.

${ }^{15}$ Renaud Barbaras, " De la phénoménologie du corps à l’ontologie de la chair », in Jean-Christophe Goddard Le corps (Vrin, Paris, 2005), 227. Renaud Barbaras Le tournant de l'expérience. Recherches sur la philosophie de Merleau-Ponty(Vrin, Paris, 1998), 95-136.
} 
appears when the body in its familiarity echoes an immemorial time of an active belonging to a space that exists before it and that marks our place in it.

The memory of the body can not be understood as a representation of cognitively defined events from the past. The body does not absorb the past in a thematic manner. Rather, the body is correlative to the style of a world that prereflexively spatializes it. In this sense, the memory of the body must first be founded on our body movements. ${ }^{16}$ The acquired spatiality that the body is immemorially made of consists of our movements as our body pre-reflectively replies to the interpellations of space. In this sense, body memory can only be understood as the re-actualization and re-enactment of gestures, postures, movements, dynamic dispositions and correspondences. Such gestures, postures, movements and dynamic correspondences must, then, be recognized as traces of the pre-personal interpellations of space.

As Merleau-Ponty points out, following a long tradition of authors such as de Maine de Biran, Felix Ravaisson, or Henri Bergson, an analysis of the phenomenon of habit is, in this context, of the utmost importance. In fact, in habit, as Merleau-Ponty demonstrates, ${ }^{17}$ we find something like an "implicit memory" ${ }^{18}$ that only the body can remember. For example, as I write this phrase on my computer, neither do I explicitly know which finger presses each key (and, if I begin to worry about this, I will most certainly stop writing), nor do I explicitly know where all the keys are. Typing rapidly “without looking” exhibits bodily memory since it depends on a constant re-enactment of movements that - so to speak - only the body knows. It manifests bodily memory because only the body can keep and actively repeat all those movements that are the

\footnotetext{
${ }^{16}$ Merleau-Ponty, Phénoménologie..., 167.

${ }^{17}$ Merleau-Ponty, Phénoménologie..., 169.

18 Thomas Fuchs « Body memory and the Unsconscious », in D. Lohmar, J. Brudziňska (ed.) Founding Psychoanalysis Phenomenologically, Phaenomenologica vol. 199 (2012), 69-82
} 
traces of a correlation (started before any thematic thought) with an always enquiring space. What we confront here is not a thematic and cognitive knowledge. It is also not a simple automatism, a simple mechanical response to an outside stimulus. These remembered movements and re-actualized responses are always immediately my own: they are rooted in my body's being-in-the-world, that is to say, in the way my body knows space and responds to it as to the other side of its own active capabilities. What is here in question is simply a "knowledge that is in the hands,"19 a kind of implicit knowing what to do that we can only explain by the fact that we are a remembering body, i.e., an active body defined by the capability to re-actualize the tacit presence of a lived spatial past.

\section{The memory of the house}

Bachelard has convincingly showed in La poétique de l'espace that such a lived correlation between body and space is the basic reference of dwelling. When we dwell we establish with, say, a house, a kind of relation in which the body incorporates the house by responding to the way the house comes to inscribe itself "physically on us" by becoming a "group of organic habits." ${ }^{20}$ For example, in visiting the house where we grew up, we run up the stairs; and "after twenty years and despite all the anonymous stairs, we rediscover the reflexions of the 'first stair'; we do not step into it a bit too high. The being of the house unfolds, faithful to our being.”"21 As this example indicates, the house has inscribed in us the functions of dwelling within it. It has made us into a

\footnotetext{
${ }^{19}$ Merleau-Ponty, Phénoménologie..., p. 168.

${ }^{20}$ Gaston Bachelard, La poétique de l'espace, (8 ed. P.U.F., Paris, 1974), 32.

${ }^{21}$ Bachelard, La poétique..., 32.
} 
diagram of its own polarities, structures, and references: to go inside and to go outside, to find shelter, do be emplaced, unplaced, displaced, to be lodged, to be comfortable, to be protected, to let the light enter, to close the windows, to feel safe from the outside world, etc. In the pact of mutual belonging, intertwining and mixture thus sealed, the act of dwelling comes into place through the body. Must we then not conclude that the memory of the body always finds itself mingled with a memory that seems to belong to (and to be gathered and kept by), for example, a house, a room, an object on the table?

Let us consider Bachelard's descriptions of the cellar, the attic, the drawers, the chest, the door, the windows. These items unfold imaginatively; we recognise them as kinds of anchors of the past: "all the past comes to live, as if by a dream, in a new house”22, writes Bachelard. He adds a few pages later: "It is thanks to the house that a large number of our memories are kept.” ${ }^{23}$ The space that dwelling places are made of is, in its nativeness, the condition of the possibility of the experience of time itself. Without our home, our bedroom, our corner, our "hideout," our storage boxes where a life is slowly archived, our chest where lost time can always be found, "intimacy would not have any model” 24 and memory would remain lost. It would be a void without these physical anchoring points. Time appears in objects, rooms, stairs, on a balcony, on a chair, in certain smells and shapes. Dwelling places are therefore fundamental and decisive elements of the experience of time. Thus Bachelard's claim is that when we return to the places that we have called "home," we find them holding memories for us, allowing us to constantly rest in the intimacy of the past. Places like our home - but also our city, our street, our neighbourhood, our landscapes - play an important role

\footnotetext{
${ }^{22}$ Bachelard, La poétique..., 35.

${ }^{23}$ Bachelard, La poétique..., 27.

${ }^{24}$ Bachelard, La poétique..., 83.
} 
regarding time since they hold the memory of our mingling with space. In Blanchard's words, such places “in my presence (...) release these memories that belong as much to the place as to my brain or body.”25

\section{The memory of the city.}

There is more to be said about dwelling. Following Ricoeur, we can say that an analysis of dwelling places (and consequently an analysis of the memory held by those places) exhibits that fact that the geometric space of built-up places is inserted between the lived corporal space and its surrounding public space. ${ }^{26}$ Thus, the spatial fabric of memory involves the consideration of the act of building,

This is an aspect that Ricoeur brings forward as he analyses "human space." In order to find human space, Ricoeur argues, we have to surpass the contradictions (aporia) that are similar to those that time exhibits. Such contradictions tend to oppose and mutually conceal the conceptions of "geometric” and "lived space.” Human space, in fact, can only be found in the rupture and suture of lived and geometric space. ${ }^{27}$ Architecture exhibits human space as dwelling. It does so by manifesting in its buildings the "remarkable composition” formed by lived corporal and geometric space.

Architecture, according to Ricoeur, must be understood as an operation where "a type of intelligibility" prevails that is analogous to the intelligibility that narrative plot ${ }^{28}$ yields with regard to time. ${ }^{29}$ In fact, like the narrative intelligibility of human time

\footnotetext{
${ }^{25}$ Casey, Getting Back..., 328

${ }^{26}$ Ricoeur, La mémoire..., 186.

${ }^{27}$ Ricoeur, La mémoire..., 186.

${ }^{28}$ Ricoeur, La mémoire..., 186. See our L. A. Umbelino, "Herméneutique, architecture et humanisation de l'espace”, in Revue d'histoire et de philosophie religieuses, Strasbourg, t. 91, 1 (2011), 67-81.

${ }^{29}$ Paul Ricoeur, “Architecture et narrativité”, in Urbanisme, no 303 (1998), 49.
} 
(which involves the rupture and suture point of lived time and cosmic time), the act of configuration of human space made possible by architecture exhibits the "point of rupture and suture of two levels of apprehension: the built-up space is also geometric space, measurable and calculable; its qualification as a place of life is superposed and tied to its geometric proprieties in the same way that narrated time intertwines together cosmic time and phenomenological time.”30

Similar to narrative's relation to the durée of time, the act of construction gives access to human space by a "plot" that is inscribed in the durability of the materials. Architecture and urbanism share with narrative the same goal of "intelligibility": both try to give a sensed form to human space. They bring together in a project with its "beginning, middle and an end” otherwise discordant materials and fragmented ideas. Narrative and architecture also share the same goal of "inter-textuallity." Like a character in a novel, an architectural proposal confronts other proposals. The building it proposes encounters the schools and influences inscribed in "the network of already existing buildings "that will contextualize the new building." ${ }^{31}$ Architecture and narrative also share the same goal of "reconfiguration." Like a book that is there to be read, ${ }^{32}$ any built-up space can only be considered to be finished through the meaningful and creative appropriation of those who dwell in them. No architectural or urbanistic project is finished - Ricoeur argues - till what was built-up offers itself to its "users" as

\footnotetext{
${ }^{30}$ Ricoeur, La mémoire..., 186.

${ }^{31}$ Ricoeur, “Architecture et narrativité”, 48. Architecture and urbanism thus put in place, regarding space, the three mimesis of narrative.

${ }^{32}$ Paul Ricoeur, Du texte à l'action. Essais d'herméneutique II (Seuil, Points Essais, 1986), 170.
} 
an occasion of "reading and re-reading our places of life starting from our way of inhabiting."33

This is an important claim made by Ricoeur. One comprehends oneself not just through the interpretation of texts, but also through the plural and attentive interpretation of the city where one dwells. ${ }^{34}$ As it synthesises heterogeneous materials, accords what is discordant, enabling the possibilities of signifying human temporal experience, the stone "book" of a city offers us alternative ways of giving meanings to our action. A city, in this way, can be read as a plot in a book of stone, as Benjamin called it. It can be taken as a book offering its readers alternative ways of understanding themselves, opening them up to a spectrum of different, polemic, decentring and alternative temporal experiences, ${ }^{35}$ this by allowing us to repossess our own human temporal existence in creative and meaningful ways. In fact, in the juxtaposition of architectonic and urbanistic styles, in the junction of the old and the new, in the relations between the monuments and new buildings, in the confrontation of the past of a decaying building or street and the promise of a new construction in an empty space, memory is kept in a point of rupture and suture between what I experientially live and what built-up spaces can live in me as I appropriate them.

This allows us to conclude something decisive regarding the spatial fabric of memory: The narrative fabric of human space unfolds the narrative fabric of human memory in the point "of rupture and suture of two levels of apprehension." This is the point where we are located by built-up places as we remember our chronotopia and tell

\footnotetext{
${ }^{33}$ Ricoeur, "Architecture et narrativité”, 49.

${ }^{34}$ Ricoeur, "Architecture et narrativité", 51.

${ }^{35}$ Ricoeur, "Architecture et narrativité”, 49.
} 
our human history through the plot that built-up spaces offer to us as we try to meaningful remember what has been or where we have been.

In any building, a sensed duration is inscribed by the durability of the materials. This durability preserves the time of the project and the time of construction; it also preserves something of the demands, hopes, and styles of the period when it was built, of the ways it was used along the years, of the personal and collective events the building witnessed. In a way, it is "at the scale of urbanism that we better understand the way time works in space” 36 - and, we can add, the way space works in time. Any built-up place is constructed in a given historical moment. As such, the voice it embodies enters into an ongoing dialogue regarding the various influence that shape our lived temporality. This dialogue embraces the worries of the present, the traditions and traumas of the past, and the hopes and dreams of the future. It appears in the old Cathedral surrounded by a renovated square, the rearrangement of an old neighbourhood, the new buildings of ecologically concerned projects, in the void left by an old building, and in the ruin bearing the weight of time (of past time in the case of the "old" ruins, of a time that never came to be, in the case of the "new" ruins of unfinished buildings and streets left vacant by economic crises. In their reconfiguration by those who dwell, a time of memory, history and forgiveness is unfolded in and through space.

\section{$\underline{4 .}$ Final words.}

Ricoeur wrote that a cemetery in a city is what gives room to absence and, at the same time, hides it. To this we would add that it conceals absence but always, thereby,

\footnotetext{
${ }^{36}$ Ricoeur, La mémoire..., 187
} 
keeps it present. Is this not a fundamental lesson regarding memory? The plot that the city opens to its readers, "the histories of life of which monuments bear the traces,”37 opens us up to a new and much needed perspective on the spatial fabric of human time. In the city, different periods in history, their realizations and expectations, persist and are kept “in reserve.” They persist where they are inscribed. They are held in reserve, waiting for the right reconfiguration. The decaying building next to the new museum, the place where the tree I used to play existed: such things hold the memory of human time, a memory inscribed in the durability of the materials that provide the sites for the events of human life. Only through them can we retell the dramatic rhythm of what counts as a human existence-namely, one that mingles known places, possible places, places we nostalgically want to go back to, places we dream of, places we call home, places that are returns, places of departures, places of absence, and places of ostensive presence. Such retelling bears witness to the fact that there are memories that only the spatial traces of past activities and sufferings, of conquests and defeats, and of joy and oblivion can preserve and hold in readiness for those who need to keep on telling their individual and collective histories. ${ }^{38}$

This leads us to our final point: the "dialogue” discussed above is possible only if those spatial traces that built-up places hold together are not reduced to "mere residues," but are both preserved and actualized as testimonies of the past-a past that can enter into dialogue with the present and the future. Reading "the book of stone" involves an obligation save memory both from active forgetfulness and from the danger

\footnotetext{
${ }^{37}$ Ricoeur, “Architecture et narrativité”, 51.

${ }^{38}$ We don't explore here the reference made by Ricoeur to the role of space as an historical figure by right as demonstrated by F. Braudel's project of a geo-history. See P. Ricoeur, La mémoire..., p. 188-191.
} 
of repetition. ${ }^{39}$ In this sense, the city must also be preserved from forgetfulness and repetition. Cities are storehouses of our possibilities of experiencing and relating human time. We need cities for the opportunity they offer us to reconstruct our memories. The gift they offer is a memory that allows the new to be actively appropriated, that gives room to "curiosity and the worry to re-organize the old to make place for the new" 40 . Without such spaces what would became of our memories?

\begin{abstract}
This paper aims to meditate on the possibilities of approaching the phenomenon of memory from the point of view of space. In order to approach memory on "the side of space." we will find our first decisive guidelines in E. Casey's ${ }^{41}$ project of a phenomenology of place, and, most of all, in Merleau-Ponty's analyses of the spatialized lived body. Starting from there, we will then try to show in what way memory, in a way, can be said to belong to places. Our point of arriving will be P. Ricoeur's proposals on the narrative dimension of human space as it allows us to consider in what sense a building or a city holds a sensed duration by inscribing it in the durability of the materials and, at the same time, in the histories of human lives
\end{abstract}

\footnotetext{
${ }^{39}$ We follow here the way Ricoeur assumes the classic contributions of Freud for the study of de resistance to remember in face of traumatic events (Gesammelte Werke de Freud, t. X, S. Ficher Verlag, 1913-1917, pp. 126-136). Ricoeur is most of all interested in what he means by «travail de mémoire » and « compulsion de répétition ». See RICOEUR, P., La mémoire..., p. 84.

${ }^{40}$ P. Ricoeur, “Architecture et narrativité”, p. 51.

41 Edward Casey, Getting Back into Place, (2nd ed., Indiana University Press, Bloomington and Indianapolis, 2009). We are following here Ricœur, La mémoire..., 185.
} 